\title{
Why Do The Students Do Disruptive Behavior In English Classroom? A Case Study on Senior High School Students in One of the Small Town in Indonesia
}

\author{
Anida Fadhilah Jati ${ }^{1}$, Endang Fauziati ${ }^{2}$, Agus Wijayanto ${ }^{2}$ \\ ${ }^{1}$ Master Degree of English Education Department Universitas Sebelas Maret, Surakarta, Indonesia, \\ ${ }^{2}$ English Education Departement Universitas Muhammadiyah Surakarta, Indonesia
}

Email corresponding author: anidafadhilah1@gmail.com

How to cite this paper: Jati, A. F., Fauziati, E., \& Wijayanto, A. (2019). Why Do the Students Do Disruptive Behavior in English Classroom? A Case Study On Senior High School Students in One of the Small Town in Indonesia . International Journal of Language Teaching and Education, 3(2), 130-141. https://doi.org/10.22437/ijolte.v3i2.7701

Accepted: November 20, 2019

Published: December 31, 2019

Copyright $\odot 2019$ International Journal of Language Teaching and Education

This work is licensed under the Creative Commons Attribution International License (CC BY 4.0). http://creativecommons.org/licenses bby $/ 4.0 /$

(c) (i)

\begin{abstract}
A conducive learning situation is essential in learning English. However, one problem that usually disturbs the learning situation is the appearance of disruptive behavior. Students' disruptive behavior is an inappropriate behavior conducted by students during the learning process which turns the classroom into not conducive. Exactly, several factors contribute to the occurrence of disruptive behavior in the classroom, especially on senior high school students. Thus, the current study was a case study aimed to investigate several causes of students' disruptive behavior in the English teaching-learning process in the classroom. The subjects of this study were seven English teachers and six selected classes from the tenth grade until the twelfth-grade students in a small town in Indonesia. The data were collected by using observation and interviews. The result of this study showed that internal factors and external factors caused students' disruptive behavior in the English classroom. Feeling boredom, feeling difficulties in learning, and seeking attention was the internal factor that became the occurrence of disruptive behavior. While fatigue and the influence of media were the external factors that cause the emergence of students' disruptive behavior in the English teachinglearning process in the classroom.
\end{abstract}

\section{Subject Areas \\ English as a Foreign Language}

\section{Keywords}

Disruptive Behavior, English Classroom, English Teaching-Learning Proses, Senior High School Students,

\section{Introduction}

Every learning has different class conditions and various students' characteristics. The students who behave well tend to produce a conducive learning environment that makes them easy to develop their way 
Anida Fadhilah Jati, Endang Fauziati, Agus Wijayanto

of thinking, so the teaching-learning process runs well, and they will quickly receive and master learning materials. While the students who make a noise and do disruptive behavior tend to interfere with the learning activity and certainly affects the ongoing teaching-learning activities.

Students' disruptive behavior can be defined as inappropriate behavior committed by a student that does not comply with the norms, value, and schools' regulation (Browne \& Gordon, 2004). Disruptive behavior occurred at every level of education, precisely in senior high school. The main reason for disruptive behavior happened in the senior high school students is because they are facing puberty phase that impacts on their emotional instability. Campbell (2013) found that there were 35.8\% of students of senior high school do disruptive behavior during the teaching-learning process. This case becomes a significant challenge to the teachers in controlling the senior high school students' behavior.

To deal with the students' disruptive behavior, many ways can be done by the teacher to prevent that problem behavior. According to Leflot, Lier, Onghena, \& Colpin (2010), giving the students reinforcement is an effort to deal with students' behavior problems in the classroom. Support focuses on student attention and increases productive learning. The various reinforcements can be in the form of giving gifts, praise, comments, gestures, teachers' body language, etc. Thus, the positive behavior of students will be formed so that student learning activities can run well without serious obstacles. Gucatan (2017) stated appropriate teacher actions such as giving students enjoyable learning activities are very useful to reduce student boredom, which can cause students' disruptive behavior in the classroom. The other method that can be done by teachers to handle disruptive behavior in the class is by managing students' behavior. Supervising the students' behavior in the classroom enhances students to do positive behavior and reduce students' disruptive behaviors (Reinke, Herman, \& Stormont, 2014). It supports the learning process.

On the contrary, Khasinah (2017) found that the way teachers prevent the students' disruptive behavior is by establishing the behavioral expectation on the first day of the semester. The expectation is in the form of a learning contract that can be based on students' attendance, arrivals, departures, class participation, full English speaking, and other appropriate behavior. So whenever students are misbehaved, teachers will directly recognize that misbehavior is out of the learning contract. In this case, teachers can find an appropriate strategy in keeping the students' behavior.

There are various types of disruptive behavior that often found by the teachers in the English classroom. According to Richard and Ranendya (2002), the types of disruptive behavior that commonly occur 
in the classroom are 1) the back row distractor, 2) the nonparticipants, and 3) over-excited students. The back row distractor refers to someone who always chooses to sit at the back row of the classroom to disturb other friends. The non-participant is a condition when the students reject to participate in the learning activities. The over-excited student is the dominant student who always monopolizes all the classroom activities. Moreover, several disruptive behaviors were found as well by Wedhanti \& Sasih (2017), namely: inattention, excessive talking, and apathy, annoying other friends, moving around, lying, disrupting others, cheating, fighting, aggression, and defiance authority.

To analyze students' misbehavior and the management used to hinder that problem, teachers first need to understand the reason behind the problem of the behavior (Turanli, 1999). The literature reveals several factors that contribute to the occurrence of students' disruptive behavior in the classroom. Based on Clayton (2000), students show disruptive behavior if they are being mistreated. Meanwhile, Flicker and Hoffan (2006, p. 12) stated that two factors may cause students' disruptive behavior those are an internal factors and external factors. Internal factor comes from the students' emotion that refers to the individual thinking and feeling to do something. Some emotions which commonly appear are temperamental personality, feeling anger, feeling opposition, feeling jealous, feeling the need for attention, feeling overstimulation, boredom, feeling frustration, feeling of fear, feeling anxiety, etc. Thus, the external factor is related to someone's physiological condition which includes starvation, malnutrition, and diseases. Furthermore, Slameto (1995) claimed that fatigue also becomes the cause of disruptive behaviors.

Concerning learning English, several factors contribute to the occurrence of students' disruptive behaviors. According to Pickett (2012), attention-seeking becomes one of the causes of disruptive behavior. It is disturbing behavior in the classroom carried out by students that aim to seek teachers' attention. Meanwhile, Zhiping and Paramasivam (2013) added that the other causes are from negative perceptions of English language lessons, shame, lack of confidence, and fear in speaking English. Negative perception means students always think bad things about English and they think English is a difficult language to be understood. Shame is an individual feeling that reflects the fear of making mistakes. Lack of confidence in the individuals' feeling that is doubtful and unsure of his ability to speak out. Fear in speaking English is much related to the students' vocabulary mastery. The more understanding the vocab is, the more students will be bolder to speak out by using English.

The theoretical review above demonstrates the importance of understanding students' disruptive behavior in the classroom. Therefore, in this study, the researcher discusses the factors that contribute to the occurrence of disruptive behavior in the English classroom in one of the senior high school in Indonesia. 
Anida Fadhilah Jati, Endang Fauziati, Agus Wijayanto

\section{Method}

This study employed a qualitative approach. Qualitative research is a broad approach to focus on social phenomena (Cresswell, 2012, p. 15). It seeks to interpret and discuss human and social phenomena in a particular setting (Ary et al., 2010). For these reasons, a qualitative study was used by the researcher since this study deals with human behavior. The researcher was intended to explain and investigate several crucial factors that contribute to the occurrence of disruptive behavior in the English teaching-learning process in the classroom.

In determining the sample size of this study, the researcher used a theoretical sample of non-probability sampling. The purpose of using theoretical sampling was to represent the answer to the research question (Setiyadi, 2006, p. 44). Thus, by considering the purpose of this study, the participants were six selected classes from the tenth grade until the twelfth-grade students and seven English teachers in one of Senior High School in the small town in Indonesia. Whereas, in gathering the data, the researcher used observation and interviews. Creswell (2012) stated that observation, interview, document, and audiovisual material were the types of data in conducting a case study.

This study employed Miles \& Huberman's (1992) analysis technique. There are three stages in the analysis, namely: data reduction, data display, and drawing conclusion/verification. In data reduction, the researcher organized and removing unnecessary data drawn from observation and interview. In the second stage, the data were analyzed systematically to answer the problems of statements in narrative form using several supporting theories related to the causes of students' disruptive behavior. In the last stage, the researcher organized the data in the form of a broad understanding containing the factor contributing to the occurrence of students' disruptive behavior in the English classroom.

To confirm the credibility of the data, triangulation was conducted. Oliga and Denzin (2006) stated that triangulation is classified into four types of triangulation, methodological triangulation, investigator triangulation, data triangulation, and theory triangulation. Two types of triangulation used in this study were data triangulation and methodological triangulation.

\section{Findings and Discussions}

After doing the observation and interview, the researcher found several factors that influence students doing disruptive behavior in the classroom. The factors were in the form of internal and external. Some of the students' disruptive behavior that belonged to internal factors were; 1) boredom, 2) learning 
difficulties, and 3) attention-seeking. On the other hand, the other factors which affect students did the disruptive behavior were 1) fatigue, and 2) the influence of media.

\subsection{Boredom}

Boredom is a condition when students are bored and unable to comprehend the subject matter in the learning process. Some teachers believe that there will be no progress in students in the form of knowledge and skills if the students experience boredom in learning English. This is because the brain system cannot work as expected. The impact of this boredom is the decreasing motivation of students towards learning activities.

In this study, boredom became one of the factors that contribute to the occurrence of students' disruptive behavior in the English classroom. This was in line with the theory of Flicker \& Hoffan (2006) who stated that boredom was an internal factor that came from students' emotions which enables students did disruptive behavior in the English teaching-learning process in the classroom. Based on the result of the interview of the participant T1 the boredom experienced by students was because of the limited English vocabulary the students have. As what the participant T1 said in the interview process about the cause of students' disruptive behavior.

"Many students know a few English vocabularies only, and it makes them bored to join English lesson because of its position as a foreign language..."(T1, 4 August 2019)

The participant T3 also delivered another opinion about the cause of students' disruptive behavior in the form of boredom in the interview result.

"In learning, I as a teacher try to provide a variety of teaching techniques to students under learning topics such as making group discussions, role-playing, games, questioning and answering, lecturing, etc. However, students only like a single technique, it is games. Of course, this will not always be done by me in every learning topic. This is what makes students bored in learning and tends not to pay attention to me when teaching. (T3, 4 August 2019)

Two teachers argued that the dominant factor that caused students to feel bored in learning English was (1) the students' difficulty towards English and, (2) inappropriate teaching strategies used by teachers. In this case, it is certainly true that many students felt difficulty in understanding English because in Indonesia English became a foreign language. So if it compared with their second language, some of them thought that English consisted of many new vocabularies and also different grammatical pattern. Besides, 
Anida Fadhilah Jati, Endang Fauziati, Agus Wijayanto

inappropriate teaching strategies were also the cause of students' boredom. In this case, the students were only happy and paid attention to the teacher if the teacher used games in his teaching technique. Furthermore, if the teacher did other teaching techniques, students would be passive and not interested in listening to the teachers' explanation and following the learning activities, even some of them did events that disturbed other friends such as talking to other friends, pinching his friends, calling others' name loudly, etc.

However, based on the observation result, the researchers also found other cases that made students bored in the class. It was related to the students who were already familiar with the English language material. Thus, they tended to simplify the materials and looked bored if the teacher always repeated the topic of learning that they had mastered. So that many of students got rid of their boredom by doing something that disrupted the ongoing teaching-learning activities.

From the data obtained from the observation and interview, it could be concluded that the students' limited vocabularies, inappropriate teaching strategies, and the repetition of learning material that students have mastered were the cause of boredom experienced by students.

\subsection{Learning Difficulties}

As a foreign language learner, there are many challenges faced by students in attending English lessons at school. Some challenges are; the students' ability to memorize and understanding vocabularies, the students' ability to use appropriate grammatical patterns, and the students' ability to understand the genre of the text, etc. Dealing with such matters, some of the students who were challenged to adopt a new language, they tend to have high motivation in joining English teaching-learning process. Their motivation could be proved by the way students' enthusiast to follow English lesson. However, for those who had difficulty in learning English, they tend to have a negative perception which significantly impacts the students' low motivation towards studying English lesson. As a result, they tend to be passive and not eager to learn. This case is strengthened by Ziping \& Paramasivam (2013), they urged that negative perceptions of English language lessons, shame, lack of confidence, and fear in speaking English are the source of being anxiety that makes students' do some activities that interfere teaching-learning activities in the classroom.

The cause of students' disruptive behavior in the form of learning difficulties was supported by the excerpt data below derived from the interview result. 
“Besides that, the students' learning difficulty is also the cause of students' negative behavior in the English classroom. They think that English is a complicated lesson because of many language rules and texts. So, some of them feel the anxiety to focus on materials given by me”.

Participant T7 delivered the same opinion in the interview.

“The second cause is the students' problem in learning English. Students use Bahasa to do communication in daily life. So, memorizing and understanding new vocabularies in learning English becomes a big problem for them.”) (T7, 4 August 2019)

Based on the findings the teacher did not mention any behavior that the students' did when they were difficulty in challenging the English lesson. However, the researcher found students' habits in the observation stage for instance; students who were passive in the class and students' who did daydreaming or sleeping in the class.

\subsection{Attention Seeking}

The fourth cause of students' disruptive behavior was attention-seeking. Attention seeking was often done by some students who wanted to be noticed by the teacher and others. However, if that behavior were shown continuously, it would attract the class situation. It was in line with Picket (2012) who stated that attention-seeking was one of the students' habits which caused students' disruptive behavior occurred in the class during the teaching-learning process.

The researcher found some students who seek attention based on the observation and interview results. The statement of participant $\mathrm{T} 2$ below indicated that attention-seeking was one of the factors that contribute to the occurrence of students' disruptive behavior in the English classroom.

"Some types of causes of students' disruptive behavior are attention-seeking, anxiety with the ability of other friends, low motivation to learn, and fatigue". (T2, 4 August 2019)

The participant T5 came up with a further opinion about attention-seeking during the learning activities in the classroom.

"Meanwhile, for those who seek attention, they tend to disturb the teacher or other students by calling aloud the teacher's name, pinching his friend, hitting the table, and shouting aloud. Actually, I felt disrupted about their activities because I have to split my mind to teach them and control their behavior". (T5, 4 August 2019) 
Anida Fadhilah Jati, Endang Fauziati, Agus Wijayanto

There was a similarity between the causes of students' misbehavior in the form of attention-seeking in the observation and interview results. According to the results of the observation, the researcher found several students who tended to seek for attention to the teacher and other friends in the class. It could be proven by some habits the students did. Some of them tried to make a joke in the middle of the lesson. Some of them laughed aloud when the teacher explained the materials, and also some students walked around the class without gaining the teacher's permission, etc. The students did it as if they hoped the teacher's attention. In fact, they stopped their action immediately when the teacher reprimanded them.

\subsection{Fatigue}

Feeling fatigued was a widespread problem felt by students. School fatigue could be in the form of sleepiness and physical fatigue, etc. This hinders students from focusing, paying attention, and understanding the topic given by the teacher. If this problem continues, it will lead to a decrease in students' motivation, inhibit effective learning process, and adversely affects students' academic achievement. This case was supported by Slameto (1995), he stated that students' fatigue caused lethargy that decreases students' willingness to follow the learning process. It happened because students were always thinking about something, facing constant things without any variation, and doing something forced which was not under their wishes.

Based on the interview result, two teachers thought that students were often tired when English lessons took place. Many reasons caused them to get bored and less enthusiastic during English lessons. The statement of the participant T2 supported the data about fatigue as one causes of students' disruptive behavior in the English classroom

"There are various reasons that cause students to do disruptive behavior in my class such as fatigue, attention-seeking, anxiety in learning, and so on. But in my opinion, the most common cause done by students is to seek attention." (T2, 4 August 2019)

Besides, the participant T4 gave a further explanation about the reason for being fatigued. He emphasized that the students' less ability to manage their time was also one of the sources of students' fatigue.

"Some students get sleepy in class and even sleep during the class. The reason is feeling fatigued. They looked burdened with the kinds of assignments given by the teacher from a different subject. So, they will feel tired if they don't have a good ability to manage their time well." (T4, 4 August 2019) 
The results of the interview data were in accordance with the results of the observation. Based on the observation, the researcher found several types of student habits that were classified as students' disruptive behavior such as daydreaming, sleepy, and sleeping during the lesson. The students seemed to have too much activity and less time to rest. Even some of them seemed to focus on doing assignments from the other subjects. So, it could not be denied that fatigue became one of many factors of students' disruptive behavior in the English classroom. Too much assignment required students to drain their energy and spent much of their time to do the tasks. It effected on decreasing students' concentration in absorbing English learning materials given by the teacher.

\subsection{The Influence of Media}

Nowadays, media is one of the important things in human life. By utilizing the media, someone can use it as a means of communication, learning, entertainment, working, searching, and so on. However, if it did not use wisely, there would be various problems, One of the issues that problems occurred in the school is the emergence of students' disruptive behavior during the lesson. Many students used media especially mobile phones not for important purposes in the middle of the learning activities. They even used it without gaining the teachers' permission and just for playing online games, taking pictures or selfies, opening the social media, etc. This case disturbed students to absorb the materials given by teachers.

The participant $\mathrm{T} 5$ and $\mathrm{T} 6$ uttered the influence of media in disturbing the ingoing teaching-learning activity in the interview.

"In my class, I often encounter some students who always use their cellphones during class. This habit has a negative effect on both me as a teacher and also the students. It breaks my concentration in conveying material and also decrease the students' concentration in absorbing the English material" (T5, 4 August 2019)

Meanwhile, the participant T6 gave a further explanation about the impact of media in determining the students' learning outcome.

"In my opinion, some of the students use mobile phones because of becoming addictions. So they always want to use a cell phone whenever, wherever, and in any situation, they are without an important purpose. It exactly disturbs the ongoing learning activities, because, the students will focus more on their mobile phone rather than paying attention to the teachers; explanation. As a result, it has a negative impact on the students' learning outcomes". (T6, 4 August 2019) 
Anida Fadhilah Jati, Endang Fauziati, Agus Wijayanto

Based on the interview result, it could be seen that the use of mobile phones gave a bad effect on both teachers and students. For the teacher, the students' habit of using a mobile phone in the middle of learning activities could attract the teachers' concentration in delivering the English materials. Meanwhile, for the students, the use of a mobile phone in an inappropriate way had a detrimental effect on the students' learning outcomes. The phenomena of being addicted to media were also supported by Beebeejaun \& Muslum (2014) they stated that adolescent behavior wee therefore negatively influenced by media in the current era of rapid technological changes.

On the other hand, based on observations, the use of mobile phones was sometimes beneficial to help students work on assignments in class. Various sources of material available on the internet enriched the students' knowledge. However, not a few of them did not obey the teacher's orders to find out material by searching on the internet, they opened social media or online games instead. This case often changed the learning atmosphere into not conducive.

\section{Conclusion}

Disruptive behavior is a major problem that cannot be taken lightly. Students who make a noise and disturb their friends during the English teaching-learning process in the classroom turn the learning situation into not conducive. If this problem continues, it adversely affects the students' academic outcomes. Related to that case, this paper examines some causes of students' disruptive behavior in the English classroom. Various factors contribute to the occurrence of students' disruptive behavior in the English learning process. Based on the result of this study, the causes are 1) boredom, 2) the influence of media, 3) fatigue, 4) attention-seeking, and 5) students' learning difficulties. Meanwhile, for the five causes found in this study, the dominant causes which were done by students in the class were attentionseeking and the influence of media. Related to this topic of this study, it would be better for the other researcher to investigate deeply about the teachers' ways of solving problems in each cause of students' disruptive behavior in the English classroom. Therefore, it enables teachers and students to focus on joining every learning activity without major obstacles which can maximize the students' academic outcome.

\section{References}

[1] Ary, D., Jacobs, L. C., Irvine, C. K. S., \& Walker, D. (2018). Introduction to research in education. Cengage Learning. 
[2] Beebeejaun-Muslum, Z. N. (2014). Delinquant and antisocial behaviour in Mauritian secondary school. Research Journal of Social Science and Management, 3(12), 124-135. Retrieved from https://www.theinternationaljournal.org

[3] Creswell, J. W. (2012) Education research: Planning, conducting, and evaluating quantitative and qualitative research, 4th Edition. University of Nebraska-Lincoln.

[4] Campbell, A., Rodrigues, B. J., \& dkk. (2013). Effects of a tier 2 on classroom disruptive behavior and academic engagement. Journal of curriculum and instruction (JOICI), 7, 35-54.

[5] Clayton, M. (2000). Professors struggle to rout out rudeness. Christian Science Monitor. Retrieved from https://www.csmonitor.com/2000/0321/p16s1.html/

[6] Denzin, N. (2006). Sociological methods: A sourcebook. $5^{\text {th }}$ Edition. Aldine Transaction. ISBN 9780-202-30840-1

[7] Flicker, E. S., \& Hoffman, J. A. (2006). Guiding children's behavior. New York and London: Teacher College Press.

[8] Gacutan, M. J. (2017, October 25, 14.30). 3 big reasons for student misbehavior. Retrieved from http://thefilipinoteacher.com/2017/04/01/3-big-reasons-student-misbehavior/

[9] Gordon, A. M., \& Browne, K. W. (2004). Beginning and Beyond: Foundations in early childhood education. Australia: Delmar Learning.

[10] Khasinah, S. (2017). Managing disruptive behavior of students in the language classroom. Englisia Journal of Language Education, and Humanities, 4(2). http://dx.doi.org/10.22373/ej.v4i2.1661

[11] Leflot, G., Van, L. P., Onghena, P., \& Colpin, H. (2010). The role of teacher behavior management in the development of disruptive behaviors: An intervention study with the good behavior game. Journal Abnorm Child Psychology, 869-882. https://doi.org/10.1007/s10802-010-9411-4

[12] Miles, Matthew B. \& Huberman, A. Michael., (1992). Analisis Data Kualitatif: Buku Sumber Tentang Metode-metode Baru. Penerjemah, Tjetjep Rohendi Rohidi. Jakarta: UI Press.

[13] Pickett, C. (2012, October 25, 01.45). Why students do misbehave. Retrieved from https://teachertalkers.wikispaces.com/Why+do+Students+Misbehave/

[14] Reinke, W. M., Stormont, M., Keith, C., Herman., Wang, Z., Newcomer, L., King, K. (2014). Use of coaching and behavior support planning for students with disruptive behavior withing a universal classroom management program. Journal of Emotional and Behavioral Disorder. 22(2), 74-82. https://doi.org/10.1177/1063426613519820

[15] Richards, J. C., \& Renandya, W. A. (2002). Methodology in language teaching: an anthology of current practice. Cambridge: Cambridge University Press.

[16] Setiyadi, A., Bambang. (2006). Metode penelitian untuk pengajaran bahasa asing Bandar Lampung pendekatan kuantatif dan kualitatif. Yogyakarta: Graha Ilmu. 
Anida Fadhilah Jati, Endang Fauziati, Agus Wijayanto

[17] Slameto. (1995). Belajar dan faktor-faktor yang mempengaruhinya. Jakarta: Rineka Cipta.

[18] Turanl, A. S. (1999). Influence of teachers' orientations to classroom management on their classroom behaviours, students' responses to these behaviours, and learning environment in ELT classrooms. (Unpublished MA Thesis, Middle East Technical University, Institute of Social Sciences, Ankara, Turkey).

[19] Wedhanti, N. K., \& Sasih, L. L. (2017). An analysis of classroom students' misbehaviors in mechanical engineering department class of grade XI in SMK Negeri 3 Singaraja. International Journal of Language and Literature, 1, 89-96. http://dx.doi.org/10.23887/ijll.v1i1.9622

[20]Zhiping, D., \& Paramesivam, S. (2013). Anxiety of speaking English in class among international students in a Malaysian university. International Journal of Education and Research, 1(11). Retrieved from http://www.ijern.com/journ/ 